\title{
Evaluasi Tata Kelola Sistem Informasi Akademik Berbasis COBIT 5 di Universitas Pendidikan Ganesha
}

\author{
I Gusti Lanang Agung Raditya Putra ${ }^{1}$, Benyamin Langgu Sinaga ${ }^{2}$, Irya Wisnubhadra ${ }^{3}$ \\ Program Studi Magister Teknik Informatika, Program Pasca Sarjana, Universitas Atma Jaya Yogyakarta \\ Jl. Babarsari 43, Yogyakarta 55281 \\ E-mail: 1la.raditya27@gmail.com
}

Masuk: 14 April 2015; Direvisi: 4 Mei 2015 dan 11 Mei 2015; Diterima: 12 Mei 2015

\begin{abstract}
This research is aimed to evaluate the maturity level of IT governance in the implementation of academic information system services at Universitas Pendidikan Ganesha. The method employed is a mix of quantitative and qualitative methods by using a questionnaire, interview, and document research. The foci of this research are in several domains of COBIT 5 including, EDM4, APO7, and BAI4. Source of data obtained from the chair person of the computer center office, the IT staff on computer center office, the IT staff on faculty, and the vice dean of academic affairs. The analysis was done by descriptive interpretative based on COBIT 5. Research results show that IT governance on academic information system services at Universitas Pendidikan Ganesha operates quite well as the maturity level currently reaches level 3 (established). This result is compared with the expected maturity level of 5 (optimizing), the comparison of the result is obtained by the value of the gap. The value of the gap is used to formulate recommendations for improvement. For the improvement of IT governance it is recommended that agencies to prepare competent human resources, as well as documenting every evaluation activities, directing, and monitoring the management of academic information system.
\end{abstract}

Keywords: IT Governance, COBIT 5, Maturity Level.

\begin{abstract}
Abstrak. Penelitian ini bertujuan untuk mengevaluasi tingkat kematangan tata kelola teknologi informasi (TI) dalam penerapan layanan sistem informasi akademik (SIAK) di Universitas Pendidikan Ganesha. Metode yang digunakan adalah metode campuran kuantitatif dan kualitatif menggunakan instrumen kuesioner, wawancara, dan studi dokumen. Fokus penelitian ini pada beberapa domain COBIT 5 meliputi, EDM4, APO7, dan BAI4. Sumber data diperoleh dari Kepala Pusat Komputer (Puskom), staf TI Puskom, staf TI fakultas, dan pembantu dekan I. Analisis penelitian dilakukan dengan cara deskriptif interpretatif berbasis COBIT 5. Hasil penelitian menunjukkan tingkat kematangan tata kelola TI pada layanan SIAK Undiksha saat ini berada pada tingkat tiga (established). Hasil ini dibandingkan dengan tingkat kematangan yang diharapkan yaitu tingkat lima (optimizing), dari hasil perbandingan tersebut diperoleh nilai kesenjangan. Nilai kesenjangan digunakan untuk merumuskan rekomendasi perbaikan. Untuk perbaikan tata kelola TI disarankan agar lembaga mempersiapkan SDM yang kompeten, serta mendokumentasikan setiap kegiatan evaluasi, pengarahan, dan monitoring dalam pengelolaan SIAK.
\end{abstract}

Kata Kunci: Tata Kelola TI, COBIT 5, Tingkat Kematangan.

\section{Pendahuluan}

Pemanfaatan TI di sebuah lembaga pendidikan tinggi secara teori diyakini memberikan kemudahan dan efisiensi dalam kaitan dengan sistem administrasi. Namun demikian, untuk mencapai kemudahan dan efisiensi administrasi dalam penerapan memerlukan tata kelola yang baik. Tujuan strategis dapat tercapai jika strategi yang telah direncanakan, dibuat, dan diterapkan, dikelola dengan baik. Sistem teknologi informasi yang terkelola dengan baik merupakan salah satu sumber daya yang penting, karena dengan teknologi informasi yang 
terkelola dengan baik memberi kontribusi besar dalam menyediakan layanan pendidikan sesuai dengan tujuan organisasi. Salah satu cara yang dilakukan dengan menciptakan sebuah sistem informasi akademik (SIAK). Akan tetapi, penggunaan TI dalam mendukung layanan SIAK di Undiksha memunculkan resiko tingginya biaya investasi, baik dari segi pengadaan perangkat keras, pengembangan perangkat lunak, implementasi serta pemeliharaan sistem. Pada tahun 2012 Undiksha menganggarkan biaya pengadaan peralatan dan sarana TI sebesar Rp. 10.000.000.000,- (sepuluh miliar rupiah). Anggaran untuk investasi SIAK sekitar 15\%-20\%. Hal ini dilakukan dengan harapan mampu mewujudkan tujuan organisasi (Universitas Pendidikan Ganesha, 2012). Biaya operasional untuk layanan SIAK, bersifat tahun anggaran, biaya pada setiap tahun disesuaikan dengan kebutuhan dan keadaan keuangan lembaga.

Layanan SIAK yang dilaksanakan oleh Undiksha belum optimal seperti yang diharapkan. Masalah yang terjadi antara lain keterlambatan proses unduh nilai dan registrasi perkuliahan (KRS). Dosen sebagian besar menginput nilai pada batas hari terakhir penjadwalan, kinerja sistem lambat atau sistem belum mampu bekerja optimal ketika banyak dosen menginput nilai pada waktu yang bersamaan. Staf TI pada masing-masing fakultas tidak fokus dalam mengurus TI khususnya sistem informasi akademik, karena tugas ini sebagai tugas tambahan. (Raditya, 2015). Masalah-masalah yang tersebut di atas terkait dengan beberapa aspek/domain yang tertera di dalam teori COBIT 5 diantaranya adalah mengatur persediaan dan kapasitas sistem (BAI4), pengoptimalan sumber daya (EDM4), pengaturan sumber daya manusia (APO7) (ISACA, 2012).

Mengamati kondisi tersebut di atas nampak ada kesenjangan antara yang direncanakan dengan realitas yang terjadi. Kesenjangan yang terjadi berkaitan dengan sistem tata kelola SIAK yang dilaksanakan. Sistem tata kelola SIAK dipandang perlu untuk dikaji lebih mendalam dengan melakukan evaluasi tata kelola. Evaluasi tata kelola diperlukan untuk mencari tahu bagaimana pelaksanaan tata kelola, bagaimana tingkat kematangan tata kelola yang telah dilakukan, dan masalah-masalah apa yang dihadapi, sehingga dapat diusahakan jalan keluar dan rekomendasi yang tepat untuk peningkatan dan pengembangan. Cara penelitian evaluasi yang dilakukan berdasarkan kerangka kerja COBIT 5, yang dimodifikasi disesuaikan dengan kondisi di tempat penelitian. Modifikasi yang dilakukan yaitu mengukur beberapa aktivitas kegiatan yang diturunkan dari beberapa domain yang ada pada COBIT 5.

Berdasarkan beberapa hal yang dikemukakan di atas masalah yang dibahas yaitu: (1) Bagaimanakah tingkat kematangan tata kelola teknologi informasi dalam layanan sistem informasi akademik di Universitas Pendidikan Ganesha? (2) Rekomendasi apakah yang dapat diberikan dalam upaya perbaikan tata kelola teknologi informasi dalam layanan sistem informasi akademik di Universitas Pendidikan Ganesha?

Dalam penelitian terdapat batasan-batasan yaitu: (1) Penelitian terbatas pada tata kelola TI dalam layanan sistem informasi akademik pada Universitas Pendidikan Ganesha Singaraja Bali. (2) Penentuan proses-proses tingkat pengelolaan TI menggunakan framework COBIT 5, pada domain EDM 4 (memastikan pengoptimalan sumber daya), APO 7 (mengatur sumber daya manusia), dan BAI 4 (mengatur persediaan dan kapasitas sistem). (3) Model assessment proses COBIT 5 ini mengacu pada konsep model tingkat kapabilitas ISO/IEC 15504.

\section{Tinjauan Pustaka}

\subsection{Penelitian Terdahulu}

Evaluasi terhadap tata kelola teknologi informasi menggunakan COBIT framework telah banyak diteliti dan hasil rekomendasinya dapat membantu Universitas memperbaiki tata kelola TI menjadi lebih baik. Seperti penelitian yang dilakukan Adikara (2013), dalam penelitiannya membahas tentang implementasi kerangka kerja COBIT 5, memberikan langkahlangkah untuk meningkatkan kinerja serta rekomendasi perencanaan tata kelola di masa yang akan datang. Evaluasi yang dilakukan hanya pada area tata kelola tidak mengevaluasi area manajemen. Penelitian dalam bidang yang sama juga telah dilakukan oleh Ade, dkk. (2012), hasil dari kajian yang dilakukan adalah membuat pengukuran kinerja sistem informasi akademik yang berupa analisa, pemetaan maturity pada aktivitas domain Plan and Organize (PO) 
menggunakan COBIT 4.1, dan rekomendasi bagi Universitas Singaperbangsa Karawang. Penilaian kuesioner pada penelitian ini dari top management sampai tingkat operasional dianggap sama, menyebabkan terjadinya bias pada pengisian kuesioner.

Evaluasi menggunakan COBIT juga dilakukan Purwanto (2010), dalam penelitiannya membahas bagaimana COBIT 4.1 khususnya pada proses deliver and support (DS) dan monitor evaluate (ME) dapat membantu Universitas Budi Luhur mengetahui tingkat keselarasan rencana strategi TI dengan strategi bisnis yang telah ditetapkan, hasil analisis tingkat kematangan pada proses DS dan ME berada pada tingkat 2, selanjutnya digunakan untuk rekomendasi pengoptimalan kualitas layanan SIAK Universitas Budi Luhur. Penelitian ini tidak mengelompokkan tingkat pengisian kuesioner, maka hasil kuesioner masih diragukan, sehingga berdampak pada rekomendasi yang diberikan menjadi tidak tepat.

Setiawan (2008), dalam penelitiannya membahas tentang evaluasi penerapan teknologi informasi di Perguruan Tinggi Swasta Yogyakarta dengan menggunakan model COBIT 4.1 framework seluruh domain proses. Hasil penelitiannya menyatakan evaluasi dengan COBIT 4.1 sangat berguna baik bagi pengguna, pengembang teknologi informasi maupun pengelola, agar pihak manajemen dapat melakukan perbaikan. Penelitian ini tidak mejelaskan detail subjek penelitian dan menggunakan seluruh domain proses COBIT 4.1, serta objek penelitian yang luas di 50 Perguruan Tinggi Swasta, berdampak pada tingkat keakuratan hasil penelitian.

Berdasarkan tinjauan pustaka diatas maka penulis menyimpulkan bahwa COBIT framework merupakan model yang tepat dan telah banyak digunakan untuk melakukan evaluasi terhadap tata kelola teknologi informasi khususnya pada Perguruan Tinggi yang mengimplementasikan teknologi informasi dalam proses bisnisnya. Pada penelitian ini framework COBIT 5 digunakan penulis untuk mengevaluasi tingkat kematangan tata kelola TI, karena COBIT 5 membagi proses tata kelola dan manajemen TI suatu organisasi menjadi dua area proses utama, serta menyediakan petunjuk lebih detail yang dibutuhkan oleh pengguna sebagai referensi yang mudah dipahami dalam operasional TI.

\subsection{Tata Kelola TI}

Tata kelola TI (IT Governance) adalah wewenang dan tanggung jawab secara benar dalam menetapkan suatu keputusan untuk mendorong perilaku penggunaan teknologi informasi pada perusahaan. (Weill and Ross, 2004). Pentingnya manfaat tata kelola TI tidak muncul secara tiba-tiba. Tata kelola TI adalah sebuah hal yang serius (critical) dalam operasional suatu organisasi. Penerapan TI di dalam organisasi dapat dilakukan dengan baik apabila ditunjang dengan suatu tata kelola TI mulai dari perencanaan sampai implementasinya. Definisi IT Governance menurut Information Technology Governance Institute (ITGI) adalah: "Suatu bagian terintegrasi dari kepengurusan perusahaan serta mencakup kepemimpinan dan struktur serta proses organisasi yang memastikan bahwa TI perusahaan mempertahankan dan memperluas strategi bisnis dan tujuan organisasi" (ITGI, 2014).

Nova, dkk. (2012), menyatakan tata kelola TI pada intinya mencakup pembuatan keputusan, akuntabilitas pelaksanaan kegiatan penggunaan TI, siapa yang mengambil keputusan, dan mengelola proses pembuatan dan pengimplementasian keputusan-keputusan yang berkaitan dengan TI. Menurut Jogiyanto dan Abdillah (2011), mendefinisikan tata kelola TI sebagai sebuah sistem yang ada dalam organisasi, yang secara umum dibagi menjadi dua bagian utama, yaitu struktur tata kelola TI, dan proses tata kelola TI. Struktur sistem tata kelola TI terdiri atas komponen-komponen yang membangun sistem tata kelola TI, yaitu: aktiva manusia, archetype, kendali dan regulasi. Dalam konteks ini, manusia termasuk ke dalam sistem tata kelola TI, karena manusia merupakan komponen yang memiliki peran dan fungsi penting dalam merancang, membuat keputusan, melaksanakan dan mengevaluasi sistem tata kelola TI. Model kerangka sistem tata kelola TI seperti Gambar 1.

\section{Metode Penelitian}

Penelitian ini pada dasarnya adalah penelitian kualitatif yang dipadukan dengan kuantitatif (Julia, 2004). Penelitian kualitatif adalah penelitian untuk memahami fenomena 
tentang apa yang dialami oleh subjek penelitian misalnya perilaku, persepsi, motivasi, dan tindakan secara holistik. Penjelasannya dengan cara deskripsi dalam bentuk kata-kata dan bahasa pada suatu konteks khusus yang alamiah dan dengan memanfaatkan berbagai metode alamiah (Iskandar, 2008; Moleong, 2007). Jenis pendekatan yang digunakan adalah pendekatan studi kasus. Penelitian studi kasus berorientasi untuk memahami, menggali, dan menafsirkan arti dan peristiwa-peristiwa, dan hubungan dengan orang-orang yang biasa dalam kasus tertentu. Ini biasa disebut dengan penelitian kualitatif dengan menggunakan pengamatan terhadap fenomena-fenomena atau gejala-gejala sosial yang alamiah yang berdasarkan kenyataan lapangan (empiris) (Sugiono, 2013).

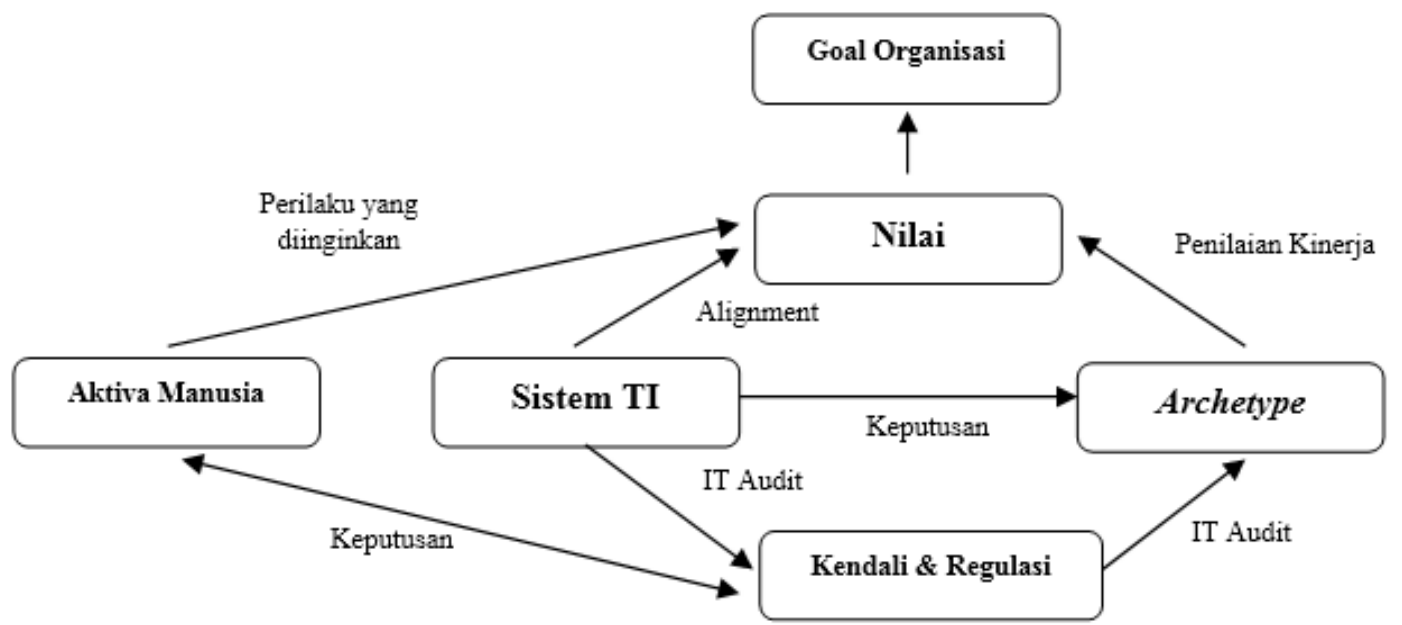

Gambar 1. Kerangka Sistem Tata Kelola TI (Jogiyanto\&Abdilah, 2011)

Kasus yang diteliti adalah evaluasi tata kelola TI khusus dalam penerapan layanan SIAK di Undiksha. Evaluasi layanan SIAK menggunakan framework COBIT 5 pada domain EDM 4 (memastikan pengoptimalan sumber daya), APO 7 (mengatur sumber daya manusia), dan BAI 4 (mengatur persediaan dan kapasitas sistem). Setelah dievaluasi, selanjutnya dilakukan penilaian berdasarkan model kapabilitas ISO/IEC 15504 untuk mengetahui tingkat kematangan tata kelola TI. Berdasarkan hasil penilaian akan digunakan untuk merumuskan rekomendasi yang mungkin diberikan sebagai perbaikan tata kelola TI dalam layanan SIAK di Undiksha.

Data atau informasi yang menjadi bahan baku penelitian untuk diolah merupakan data primer dan data sekunder. Data primer adalah data yang diperoleh melalui serangkaian kegiatan, yaitu penyebaran kuesioner, dan wawancara mendalam sedangkan, data sekunder adalah data yang diperoleh melalui pengumpulan data yang bersifat studi dokumentasi (Iskandar, 2008). Penyebaran kuesioner sebagai langkah untuk mengumpulkan data kuantitatif, sedangkan wawancara dan pengumpulan dokumen sebagai langkah untuk pengumpulan data kualitatif.

Teknik analisis data dilakukan dengan analisis campuran kuantitatif dan kualitatif. Analisis kuantitatif dengan cara mencari skor rata-rata dari hasil kuesioner, selanjutnya dilakukan pengkategorian (Iskandar, 2008). Analisis kualitatif dilakukan dengan deskriptif interpretatif dengan langkah, yaitu pengumpulan data, reduksi data, penyajian data, interpretasi data, dan penarikan simpulan atau verifikasi (Miles dan Huberman, 2007).

Berdasarkan data hasil kuesioner, wawancara, dan studi dokumen, analisis dilakukan untuk menilai tingkat kematangan tata kelola teknologi informasi pada aktivitas EDM 4, APO 7, dan BAI 4 saat ini (as-is). Pada tahap ini penulis melakukan penilaian terhadap masing-masing aktivitas berdasarkan hasil kuesioner seluruh responden. Setelah masing-masing aktivitas memeroleh nilai selanjutnya dilakukan penggabungan seluruh nilai aktivitas dan mencari ratarata untuk mendapatkan tingkat kematangan saat ini (as-is) pada tiap domain.

Target atau harapan kematangan proses TI adalah kondisi ideal tingkat kematangan aktivitas yang diharapkan. Tingkat kematangan ini digunakan sebagai acuan dalam model tata 
kelola TI SIAK Undiksha. Tingkat kematangan yang diharapkan diperoleh dari hasil wawancara dengan kepala Puskom Undiksha.

Setelah tingkat kematangan tata kelola teknologi informasi untuk saat ini (as-is) dan tingkat kematangan tata kelola teknologi informasi yang diharapkan (to-be) diperoleh, penulis melakukan perbandingan untuk analisis kesenjangan (gap analysis) terhadap tingkat kematangan tersebut. Berdasarkan perbandingan tingkat kematangan tersebut di atas akan diperoleh aktivitas yang sesuai atau tidak sesuai dengan tingkat kematangan yang diinginkan. Dari hasil analisis kesenjangan, kemudian dilakukan perbaikan terhadap aktivitas yang tidak sesuai tersebut menuju tingkat kematangan yang diharapkan. Kesenjangan antara yang diperoleh saat ini dengan yang dituju merupakan indikator dalam rumusan rekomendasi perbaikan tata kelola.

Rekomendasi perbaikan diperoleh dari hasil analisis yang dilakukan terhadap tingkat kematangan saat ini dan tingkat kematangan yang diharapkan. Perolehan rekomendasi tersebut diharapkan mampu memberikan hasil yang maksimal dalam pengelolaan teknologi informasi pada Universitas. Rekomendasi disusun dengan mempertimbangkan kondisi Universitas dari sisi SDM, kinerja sistem, dan target Universitas kedepan. Beberapa rekomendasi diambil dari sub-domain framework COBIT 5 dan disesuaikan dengan strategi dan kemampuan Universitas. Rekomendasi dapat dijalankan secara bertahap sehingga rekomendasi ini dapat digunakan dan dikembangkan oleh Universitas.

\section{Hasil dan Pembahasan}

Penentuan tingkat kematangan dilakukan pada setiap proses teknologi informasi yang dilakukan terhadap semua tingkat, mulai dari tingkat nol atau incomplete, hingga tingkat lima atau optimizing. Penentuan tingkat kematangan dilakukan dengan pengolahan data kuesioner (appendix 1: http://bit.ly/jbi643ap). Hasil yang diperoleh divalidasi melalui hasil studi dokumen. Penilaian tingkat kematangan setiap proses TI mengacu pada model ISO/IEC 15504 dan dihitung dengan Persamaan 1. Rata-rata aktivitas dihitung dengan cara total skor aktivitas yang diperoleh dari jawaban kuesioner dibagi dengan jumlah responden sebanyak 37 orang.

Maturity $=\frac{\text { E rata }- \text { rata Aktivitas }}{\text { Jumlah Soal }}$

Hasil perhitungan maturity secara keseluruhan disajikan dalam tabel-tabel. Hasil perhitungan kuesioner proses EDM 4 tertera pada Tabel 1. Hasil perhitungan kuesioner proses APO 7 tertera pada Tabel 2. Hasil perhitungan kuesioner proses BAI 4 tertera pada Tabel 3. Rata-rata hasil perhitungan kuesioner seluruh domain proses tertera pada Tabel 4.

Tabel 1. Detail Hasil Perhitungan Maturity Proses EDM 4

\begin{tabular}{|c|c|c|c|}
\hline $\begin{array}{c}\text { Aktivitas Proses } \\
\text { EDM } 4\end{array}$ & Item Pernyataan & $\begin{array}{c}\text { Total Skor } \\
\text { Aktivitas } \\
\text { Proses } \\
\end{array}$ & $\begin{array}{c}\text { Rata-rata } \\
\text { Aktivitas } \\
\text { Proses } \\
\end{array}$ \\
\hline \multirow{3}{*}{$\begin{array}{c}\text { EDM 4.1 } \\
\text { (Mengevaluasi } \\
\text { Pengelolaan } \\
\text { Sumber Daya) }\end{array}$} & $\begin{array}{l}\text { Puskom telah melakukan kegiatan evaluasi pengelolaan peralatan } \\
\text { penunjang SIAK }\end{array}$ & 120 & 3.24 \\
\hline & Puskom telah melakukan kegiatan evaluasi pengelolaan program SIAK & 122 & 3.30 \\
\hline & Puskom telah melakukan kegiatan evaluasi petugas yang mengelola SIAK & 96 & 2.59 \\
\hline \multirow{3}{*}{$\begin{array}{c}\text { EDM } 4.2 \\
\text { (Mengarahkan } \\
\text { Pengelolaan } \\
\text { Sumber Daya) }\end{array}$} & $\begin{array}{l}\text { Puskom telah melakukan kegiatan pengarahan pengelolaan peralatan } \\
\text { penunjang SIAK }\end{array}$ & 110 & 2.97 \\
\hline & Puskom telah melakukan kegiatan pengarahan pengelolaan program SIAK & 113 & 3.05 \\
\hline & $\begin{array}{l}\text { Puskom telah melakukan kegiatan pengarahan petugas yang mengelola } \\
\text { SIAK }\end{array}$ & 99 & 2.68 \\
\hline \multirow{3}{*}{$\begin{array}{c}\text { EDM } 4.3 \\
\text { (Memantau } \\
\text { Pengelolaan } \\
\text { Sumber Daya }\end{array}$} & $\begin{array}{l}\text { Puskom telah melakukan kegiatan memantau pengelolaan peralatan } \\
\text { penunjang SIAK }\end{array}$ & 112 & 3.03 \\
\hline & Puskom telah melakukan kegiatan memantau pengelolaan program SIAK & 117 & 3.16 \\
\hline & $\begin{array}{l}\text { Puskom telah melakukan kegiatan memantau petugas yang mengelola } \\
\text { SIAK }\end{array}$ & 92 & 2.49 \\
\hline & Maturity EDM 4 & & 2,95 \\
\hline
\end{tabular}


Tabel 2. Hasil Perhitungan Maturity Proses APO 7

\begin{tabular}{llc}
\hline $\begin{array}{c}\text { Aktivitas } \\
\text { Proses }\end{array}$ & \multicolumn{1}{c}{ Deskripsi Aktivitas } & Maturity \\
\hline APO 7.1 & Memelihara susunan kepegawaian yang baik & 3,27 \\
\hline APO 7.2 & Mengidentifikasi personil kunci IT & 2,09 \\
\hline APO 7.3 & Memelihara kemampuan dan kompetensi staf & 2,22 \\
\hline APO 7.4 & Mengevaluasi kinerja pegawai & 2,27 \\
\hline APO 7.5 & Merencanakan penggunaan IT untuk sumber daya manusia & 2,35 \\
\hline \multicolumn{1}{c}{ Rata-rata Maturity } & $\mathbf{2 , 4 4}$ \\
\hline
\end{tabular}

Tabel 3. Hasil Perhitungan Maturity Proses BAI 4

\begin{tabular}{llc}
\hline $\begin{array}{c}\text { Aktivitas } \\
\text { Proses }\end{array}$ & \multicolumn{1}{c}{ Deskripsi Aktivitas } & Maturity \\
\hline BAI 4.1 & Menilai kapasitas sistem dan kinerja sistem dalam menciptakan baseline & 3,26 \\
\hline BAI 4.2 & Menilai dampak kegiatan & 3,00 \\
\hline BAI 4.3 & Merencanakan kebutuhan layanan baru atau perubahan & 2,70 \\
\hline BAI 4.4 & Memantau ketersediaan kapasitas & 3,00 \\
\hline & \multicolumn{1}{c}{ Rata-rata Maturity } & $\mathbf{2 , 9 9}$ \\
\hline
\end{tabular}

Tabel 4. Rata-rata Analisis Kuesioner

\begin{tabular}{llccc}
\hline Domain Proses & \multicolumn{1}{c}{ Deskripsi Proses } & Maturity & Tingkat & Kondisi \\
\hline EDM 4 & Memastikan pengoptimalan sumber daya & 2,95 & 3 & Established \\
\hline APO 7 & Mengatur sumber daya manusia & 2,44 & 2 & Managed \\
\hline BAI 4 & Mengatur persediaan dan kapasitas sistem & 2,99 & 3 & Established \\
\hline & Rata-rata Maturity & $\mathbf{2 , 7 9}$ & $\mathbf{3}$ & Established \\
\hline
\end{tabular}

Hasil yang diperoleh dari perhitungan kuesioner digunakan sebagai acuan awal penentuan tingkat kematangan saat ini, selanjutnya dilakukan analisis dokumen untuk menentukan kesesuaian tingkat kematangan tata kelola TI dalam pelayanan SIAK di Undiksha. Analisis dokumen dilakukan dengan melihat langsung dokumen-dokumen dan melakukan interpretasi yang terkait dengan domain proses EDM 4, APO 7, BAI 4 (appendix 2: http://bit.ly/jbi643ap). Hasil analisis dokumen yang diperoleh dijabarkan pada Tabel 5.

Tabel 5. Hasil Analisis Dokumen Domain Proses

\begin{tabular}{llll}
$\begin{array}{c}\text { Domain } \\
\text { Proses }\end{array}$ & \multicolumn{1}{c}{$\begin{array}{c}\text { Nama } \\
\text { Dokumen }\end{array}$} & \multicolumn{1}{c}{ Keterangan } & Pencapaian \\
\hline EDM 4 & $\begin{array}{l}\text { Dokumen } \\
\text { Aset Puskom }\end{array}$ & $\begin{array}{l}\text { Dokumen ini mencatat tentang sumber daya (hardware, software, } \\
\text { brainware) yang dimiliki Puskom. }\end{array}$ & 75\% \\
\hline APO 7 & $\begin{array}{l}\text { Dokumen } \\
\text { SDM Puskom }\end{array}$ & $\begin{array}{l}\text { Dokumem memuat tentang struktural jabatan dan fungsional Puskom, serta } \\
\text { jumlah staf. }\end{array}$ & 40\% \\
\hline BAI 4 & Dokumen & Dokumen ini juga mencatat tentang kapasitas kerja software yang dimiliki & $80 \%$ \\
& Aset Puskom & Puskom. & 8 \\
\hline
\end{tabular}

Hasil analisis dokumen proses EDM 4 yaitu memastikan pengoptimalan sumber daya, yang dicatat pada dokumen aset puskom. Dokumen tersebut berisi tentang pemantauan dan evaluasi penggunaan sumber daya (hardware, software, brainware) dalam rangka menunjang layanan SIAK Undiksha. Pemantauan, dan evaluasi penggunaan sumber daya telah dilakukan sesuai standar operasional prosedur, dan dilakukan secara berkala setiap enam bulan, ketika sesudah masa KRS mahasiswa dilaksanakan. Namun demikian, belum dilakukan analisis lebih mendalam tentang faktor pendukung, dan penghambat penggunaan sumber daya. Berdasarkan fakta yang ada di dalam dokumen tersebut di atas, bahwa proses EDM 4 termasuk dalam ketegori largely achieved artinya terdapat bukti bahwa secara garis besar proses ini terlaksana, terkelola, didefinisikan dan mencapai tujuan. Ada kesesuaian antara hasil analisis dokumen dan analisis kuesioner yaitu tingkat kematangan proses berada pada tingkat tiga (establibhsed).

Proses APO 7 mengatur sumber daya manusia yang dicatat dalam dokumen SDM Puskom. Dokumen yang ada hanya memuat tentang struktur jabatan dan fungsional SDM Puskom, serta jumlah staf Puskom. Namun demikian, dokumen SDM Puskom belum mencatat kemampuan, kompetensi, dan kinerja pegawai. Dari fakta tersebut dapat dinyatakan bahwa tingkat kematangan proses APO 7 hanya tercapai sebagian (partially achieved), artinya proses dijalankan dan dikelola mencangkup perencanaan namun belum didefinisikan. Dari hasil 
kuesioner yang diperoleh yaitu berada pada tingkat dua (managed) sesuai dengan analisis dokumen yang ada.

Proses BAI 4 mengatur persediaan dan kapasitas sistem untuk kegiatan layanan SIAK yang dicatat pula di dalam dokumen inventaris puskom. Pencatatan tentang pemantauan dan penilaian kapasistas, serta kinerja sistem sudah sesuai dengan standar yang ditetapkan. Pencatatan dilakukan secara berkala setiap enam bulan, setelah masa KRS mahasiswa. Hasil pencatatan tersebut selanjutnya dievaluasi untuk perbaikan sistem. Namun demikian, belum dilakukan analisis yang mendalam mengenai faktor pendukung dan penghambat kinerja sistem. Berdasarkan fakta tersebut di atas, tingkat kematangan proses BAI 4 termasuk kategori largely achieved karena terdapat bukti bahwa secara garis besar proses ini terlaksana, terkelola, terdefinisi, dan mencapai tujuan. Dari analisis kuesioner yang diperoleh selanjutnya dicocokkan dengan dokumen yang ada, tampak sesuai berada pada tingkat tiga (established).

Hasil perhitungan tingkat kematangan proses tata kelola teknologi informasi dalam pelayanan SIAK di Undiksha saat ini benar diperoleh rata-rata sebesar 2,79 setelah dilakukan validasi analisis dokumen. Dari nilai ini dapat ditarik kesimpulan bahwa pengelolaan teknologi informasi dilakukan secara established, artinya pada tingkat ini proses yang telah dibangun kemudian diimplementasikan sesuai dengan proses yang telah didefinisikan atau yang telah ditentukan, dan mampu untuk mencapai hasil dari proses tersebut. Pengelolaan lebih lanjut perlu ditingkatkan dan dikembangkan untuk mencapai tingkat lima berdasarkan tingkat kematangan yang diharapkan Undiksha. Rangkuman tingkat kematangan proses dijabarkan pada Tabel 6.

Tabel 6. Tingkat Kematangan Proses

\begin{tabular}{llccc}
\hline Domain Proses & \multicolumn{1}{c}{ Deskripsi Proses } & $\begin{array}{c}\text { Maturity } \\
\text { Saat Ini }\end{array}$ & Validasi Dokumen & $\begin{array}{c}\text { Maturity } \\
\text { Diharapkan }\end{array}$ \\
\hline EDM 4 & Memastikan pengoptimalan sumber daya & 2,95 & largely achieved & 5 \\
\hline APO 7 & Mengatur sumber daya manusia & 2,44 & partially achieved & 5 \\
\hline BAI 4 & Mengatur persediaan dan kapasitas sistem & 2,99 & largely achieved & 5 \\
\hline
\end{tabular}

Berdasarkan nilai kematangan saat ini yang diperoleh dari hasil analisis kuesioner dan analisis dokumen jika dibandingkan dengan tingkat yang diharapkan, ternyata masih terdapat kesenjangan. Kesenjangan yang ada pada masing-masing domain selanjutnya dilakukan analisis. Analisis ini diharapkan dapat memberikan kemudahan bagi pengelolaan teknologi informasi yang serasi pada tiga domain tersebut di atas. Analisis ini menunjukkan kesenjangan/gap antara tingkat kematangan saat ini dengan tingkat kematangan yang diharapkan, tertera pada Tabel 7.

Tabel 7. Perbandingan Tingkat Kematangan

\begin{tabular}{lccc}
\hline \multirow{2}{*}{ Domain Proses } & \multicolumn{3}{c}{ Tingkat Kematangan } \\
\cline { 2 - 4 } & Saat Ini & Diharapkan & Gap $=($ diharapkan - saat ini $)$ \\
\hline EDM 4 & 2,95 & 5 & $5-2,95=2,05$ \\
\hline APO 7 & 2,44 & 5 & $5-2,44=2,56$ \\
\hline BAI 4 & 2,99 & 5 & $5-2,99=2,01$ \\
\hline \multicolumn{1}{c}{ Rata-rata } & \multicolumn{3}{c}{$\mathbf{2 , 2 0}$} \\
\hline
\end{tabular}

Rata-rata gap pada seluruh domain proses yang diteliti sebesar 2,20. Dibutuhkan penyesuaian masing-masing domain proses, karena nilai 2,20 merupakan nilai rata-rata seluruh domain proses, maka penulis akan memberikan rekomendasi pada tiap proses yang diteliti, sehingga rekomendasi perbaikan yang diberikan tepat sasaran. Perbedaan kondisi kesenjangan tata kelola seluruh domain proses saat ini dengan tata kelola yang diharapkan, dapat dilihat pada Gambar 2.

Berdasarkan hasil evaluasi yang telah dilakukan di Undiksha, maka nilai-nilai temuan dicocokan pada kondisi kematangan pada masing-masing domain COBIT 5, dari hasil tersebut kemudian dianalisis temuan masalah, selanjutnya diberikan rekomendasi. 


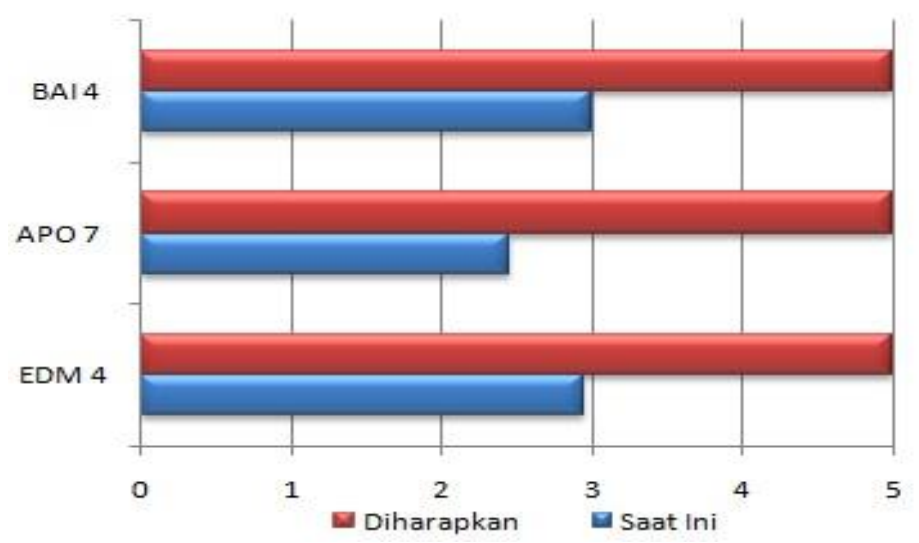

Gambar 2. Perbandingan kesenjangan kondisi tata kelola saat ini dengan tata kelola yang diharapkan

Analisis yang telah dilakukan pada domain EDM 4, masih terdapat beberapa aspek yang belum dilakukan secara maksimal, antara lain: (1) Kegiatan monitoring kepada petugas yang mengelola SIAK, dilakukan tidak secara langsung ke fakultas, melainkan hanya monitoring melalui sistem. Masalah yang muncul di tingkat fakultas yaitu, ketika terjadi perubahan dosen pengajar pada salah satu mata kuliah di awal semester, yang sesungguhnya dilaporkan kepada petugas TI fakultas, dengan harapan petugas TI fakultas, mengubah nama pengajar. Namun demikian, dalam kenyataannya pada akhir semester ketika dosen pengajar bersangkutan menginput nilai mata kuliah ke dalam SIAK, ternyata tidak muncul. Hal ini terjadi karena petugas TI fakultas belum mengubah dosen pengajar mata kuliah tersebut. (2) Kegiatan pengarahan pengelolaan program SIAK belum dilakukan secara maksimal khususnya kepada pengguna SIAK. Masalah yang muncul yaitu, masih ada beberapa dosen yang belum bisa mengoperasikan program SIAK, sehingga pada saat menginput nilai tidak dilakukan sendiri, tetapi dengan cara meminta bantuan kepada petugas TI fakultas. Kondisi ini menyebabkan petugas TI fakultas menerima beban kerja tambahan yang memengaruhi kinerja utamanya.

Rekomendasi perbaikan yang dapat dilakukan untuk mengatasi masalah diatas adalah sebagai berikut. (1) Rekomendasi Jangka Pendek (2015-2018): (a) Puskom perlu memfasilitasi atau menginisiasi untuk melakukan sosialisasi dan pelatihan kepada pengguna layanan SIAK khususnya dosen dan mahasiswa. (b) Menerbitkan buku petunjuk penggunaan layanan SIAK. (2) Rekomendasi Jangka Panjang (2015-2020): (a) Kegiatan monitoring kepada petugas yang mengelola SIAK, dilakukan secara langsung ke fakultas, agar kinerja petugas TI fakultas maksimal. (b) Dibuat sistem presensi mata kuliah yang terintegrasi dari SIAK ke fakultas, agar data mahasiswa sinkron.

APO 7 digolongkan pada tingkat dua (manage), karena Undiksha dalam kegiatan mengatur sumber daya manusia sudah dilakukan, mencapai tujuan, dan terkelola, namun demikian belum mencapai pada kategori standar. Kondisi ini disebabkan karena beberapa faktor antara lain: (1) Staf TI di fakultas tidak fokus dalam menangani SIAK, karena yang dimaksud Staf TI fakultas sesungguhnya adalah staf pegawai bagian perlengkapan yang diberikan tugas tambahan mengelola TI. (2) Staf TI yang bertugas di masing-masing fakultas tidak seluruhnya memiliki kompetensi dalam bidang TI.

Rekomendasi perbaikan yang dapat dilakukan untuk mengatasi masalah diatas adalah sebagai berikut. (1) Rekomendasi Jangka Pendek (2015-2018): (a) Peningkatan komitmen kerja staf TI dengan cara memberikan motivasi yang optimal. (b) Mengatasi masalah yang muncul dengan secepat mungkin melalui koordinasi yang intens. (2) Rekomedasi Jangka Panjang (2015-2020): (a) Lembaga hendaknya merekrut staf pegawai yang kompeten pada bidang TI untuk ditugaskan sebagai tenaga khusus menangani TI di fakultas. (b) Puskom perlu memberi pelatihan kepada seluruh staf TI fakultas agar mampu melaksanakan tupoksi dengan baik dan benar. 
Berdasarkan informasi yang diperoleh terkait dengan domain BAI 4, bahwa kapasitas server yang dimiliki Puskom Undiksha, mampu diakses 12.000 user secara bersamaan, akan tetapi pada kenyataannya ketika SIAK diakses oleh 4.000 user secara bersamaan sistem mengalami gangguan. Kondisi ini sebagai masalah yang perlu diupayakan pemecahan untuk perbaikan.

Rekomendasi perbaikan yang dapat dilakukan untuk mengatasi kesenjangan di atas adalah sebagai berikut. (1) Rekomendasi Jangka Pendek (2015-2018): (a) Dilakukan perbaikan sistem agar sesuai dengan kapasitas server. (b) Jika perbaikan sistem belum dapat dilakukan maka untuk mengatasi gangguan tersebut dilakukan dengan cara penjadwalan akses masuk SIAK. (2) Rekomendasi Jangka Panjang (2015-2020): (a) Perlu dilakukan perbaikan, dan pengembangan sistem agar layanan menjadi lancar. (b) Perlu melakukan pengembangan sistem untuk layanan kegiatan SIAK yang lain, seperti memantau proses perkuliahan.

\section{Penutup \\ 5.1 Kesimpulan}

Pelaksanaan tata kelola TI dalam layanan SIAK di Undiksha yang dianalisis menggunakan COBIT 5, meliputi domain EDM 4, APO 7, dan BAI 4, sudah dilakukan dengan cukup baik. Tingkat kematangan tata kelola teknologi informasi dalam layanan sistem informasi akademik di Universitas Pendidikan Ganesha adalah 2,79 berada pada tingkat tiga yang bermakna bahwa pengelolaan teknologi informasi dilakukan secara Established. Untuk meningkatkan tingkat kematangan dari tingkat tiga ke tingkat lima sesuai yang diharapkan maka rekomendasi sebagai berikut. (1) Rekomendasi jangka pendek (2015-2018) antara lain: (a) Puskom perlu memfasilitasi atau menginisiasi untuk melakukan sosialisasi dan pelatihan kepada pengguna layanan SIAK khususnya dosen dan mahasiswa. (b) Menerbitkan buku petunjuk penggunaan layanan SIAK. (c) Peningkatan komitmen kerja staf TI dengan cara memberikan motivasi yang optimal. (d) Mengatasi masalah yang muncul dengan secepat mungkin melalui koordinasi yang intens. (e) Dilakukan perbaikan sistem agar dapat digunakan secara maksimal. (f) Jika perbaikan sistem belum dapat dilakukan maka untuk mengatasi gangguan tersebut dilakukan dengan cara penjadwalan akses masuk SIAK. (2) Rekomendasi jangka panjang (2015-2020): (a) Kegiatan monitoring kepada petugas yang mengelola SIAK, dilakukan secara langsung ke fakultas, agar kinerja petugas TI fakultas maksimal. (b) Dibuat sistem presensi mata kuliah yang terintegrasi dari SIAK ke fakultas, agar data mahasiswa sinkron. (c) Lembaga hendaknya merekrut staf pegawai yang kompeten pada bidang TI untuk ditugaskan sebagai tenaga khusus menangani TI di fakultas. (d) Puskom perlu memberi pelatihan kepada seluruh staf TI fakultas agar mampu melaksanakan tupoksi dengan baik dan benar. (e) Perlu dilakukan perbaikan, dan pengembangan sistem agar layanan menjadi lancar. (f) Perlu melakukan pengembangan sistem untuk layanan kegiatan SIAK yang lain, seperti memantau proses perkuliahan.

\subsection{Saran}

Berdasarkan hasil penelitian yang dilakukan peneliti memiliki beberapa saran yang dapat dipertimbangkan oleh Puskom Undiksha untuk memperbaiki tata kelola TI dalam layanan SIAK, dan saran bagi peneliti selanjutnya.

Adapun saran yang dimaksud adalah sebagai berikut. (1) Langkah pertama dengan cara meningkatkan tata kelola pada domain EDM 4, APO 7, dan BAI 4, sesuai rekomendasi yang telah diberikan penulis. (2) Mempersiapkan SDM yang kompeten, melakukan transfer pengetahuan dari ahli kepada staf TI yang terkait dalam pengelolaan SIAK melalui pelatihan dan magang. (3) Mendokumentasikan setiap kegiatan evaluasi, pengarahan, dan monitoring yang berkaitan dengan pengelolaan SIAK. (4) Rekomendasi yang diberikan agar dimuat pada dokumen rencana strategis (RENSTRA) Undiksha tahun 2015-2019. (5) Pada penelitian selanjutnya diharapkan melakukan evaluasi tata kelola TI dalam layanan SIAK Undiksha dengan COBIT 5 pada domain yang berbeda. 


\section{Referensi}

Ade, A., Jajuli, M., dan Siwi, K.T. 2012. Pengukuran Kinerja Sistem Informasi Akademik dengan Menggunakan Kerangka Kerja COBIT 4.1 pada Domain Plan and Organize di Universitas Singaperbangsa Karawang. Majalah Solusi Unsika ISSN 1412-86676 vol.10 no. 22.

Adikara, F. 2013. Implementasi Tata Kelola Teknologi Informasi Tinggi Berdasarkan COBIT 5 pada Laboratorium Rekayasa Perangkat Lunak Universitas Esa Unggul. Seminar Nasional Sistem Informasi Indonesia (SESINDO), Bali 2-4 Desember 2013.

ITGI. 2014. IT Governance, (Online), (http://www.itgi.org/About_IT_Governance, diakses 20 September 2014)

ISACA. 2012. COBIT 5: Enabling Processes Governance and Management Practices, USA: ISACA \& ITGI.

Iskandar. 2008. Metodologi Penelitian Pendidikan dan Sosial (Kuantitatif dan Kualitatif). Jakarta: GP Press.

Jogiyanto, H.M., Abdilah, W. 2011. Sistem Tatakelola Teknologi Informasi. Yogyakarta: Andi Offset.

Julia, Brannen. 2004. Memadu Metode Penelitian Kualitatif dan Kuantitatif. Terjemahan oleh H. Nuktah Arfawie Kurde. Yogyakarta: Pustaka Pelajar.

Miles, M.B. dan Huberman, A.M. 2007. Analisis Data Kualitatif. Terjemahan oleh Tjetjep Rohendi Rohidi. Jakarta: UI Press.

Moleong, L.J. 2007. Metodologi Penelitian Kualitatif. Bandung: Remaja Rosdakarya.

Nova, R., Budi, W., Desi, A.S. 2012. Tingkat Kematangan Tata Kelola Teknologi Infomasi Universitas XYZ Domain Monitor and Evaluate (ME) Framework COBIT 4.0. Seminar Nasional Teknologi dan Komukasi Terapan (SEMANTIK) ISBN 979-26-0255-0, Semarang 23 Juni 2012.(5): 158-162.

Purwanto. 2010. Evaluasi Tata Kelola Teknologi Informasi Menggunakan Kerangka Kerja COBIT dalam Mendukung Layanan Sistem Informasi Akademik Studi Kasus: Universitas Budi Luhur. Jurnal TELEMATIKA MKOM ISSN 2085-725X vol.2 no 1, Maret 2010.(11): 41-51.

Raditya, I.G.L.A. 2015. Evaluasi Tata Kelola Teknologi Informasi Berbasis COBIT 5 dalam Pelayanan Sistem Informasi Akademik di Universitas Pendidikan Ganesha. Tesis tidak diterbitkan. Yogyakarta: Universitas Atma Jaya Yogyakarta.

Setiawan, A. 2008. Evaluasi Penerapan Teknologi Informasi di Perguruan Tinggi Swasta Yogyakarta dengan Menggunakan Model COBIT Framework. Seminar Nasional Aplikasi Teknologi Informasi (SNATI) ISSN: 1907-5022, Yogyakarta 21 Juni 2008. (6): A15-A20.

Sugiono. 2013. Memahami Penelitian Kualitatif. Bandung: Alfabeta.

Universitas Pendidikan Ganesha. 2012. Rencana Umum Pengadaan Barang dan Jasa Tahun Anggaran 2012. Singaraja: Undiksha.

Weill, P., dan Ross, J.W. 2004. IT Governance: how top perfomers manage IT decision rights for superior result. Boston: Harvard Business School Press. 